\title{
Pathophysiology of antibiotic resistance: Clarithromycin
}

\author{
Diane E Taylor PhD
}

\begin{abstract}
DE Taylor. Pathophysiology of antibiotic resistance: Clarithromycin. Can J Gastroenterol 2000;14(10):891-894. Resistance of Helicobacter pylori to antibiotics ranges from $3 \%$ to $10 \%$ and may exceed these levels in some countries. The pathophysiology of clarithromycin resistance is reviewed, including the mode of action by which the antibiotic inhibits protein synthesis and the mechanism of resistance, which involves a mutation at position 2142 or 2143 in the V loop domain of the 23S rRNA genes. Mutations of $\mathrm{A} 2142 \mathrm{G}$ confer a higher minimum inhibitory concentration than mutations of A2143G. The former demonstrate crossresistance to macrolide, lincosamide and streptogramin antibiotics, whereas the latter are susceptible to streptogramin B. In vitro mutagenesis combined with natural transformation were used to create several types of clarithromycin-resistant mutants. H pylori strains with $\mathrm{A} 2142 \mathrm{G}$ and $\mathrm{A} 2143 \mathrm{G}$ mutations had a higher growth rate than those with A2142C, A2143 or A2142T mutations. Data from this study indicate why clarithromycin-resistant clinical isolates of $\mathrm{H}$ pylori are more likely to have A2142G or A2143G mutations and only occasionally A2142C mutations.
\end{abstract}

Key Words: Antibiotic resistance; Clarithromycin; Helicobacter pylori

\section{Pathophysiologie de la résistance aux antibiotiques : Clarithromycine}

RÉSUMÉ : La résistance d'Helicobacter pylori aux antibiotiques varie de 3 à $10 \%$ et pourrait excéder ces taux dans certains pays. La pathophysiologie de la résistance à la clarithromycine a été passée en revue, notamment le mode d'action par lequel l'antibiotique inhibe la synthèse de la protéine et le mécanisme de résistance qui repose sur une mutation à la position 2142 ou 2143 du domaine de la boucle $V$ des gènes 23S ARNt. Les mutations de l'A2142G confèrent une concentration minimum inhibitrice plus élevée que les mutations de l'A2143G. Les premières s'accompagnent d'une résistance croisée aux macrolides, au lincosamide et à la streptomycine alors que les secondes sont sensibles à la streptogramine $\mathrm{B}$. La mutagenèse in vitro, combinée à la transformation naturelle, a été utilisée pour créer divers types de mutants résistant à la clarithromycine. Les souches d'H. pylori porteuses des mutations A2142G et A2143G présentaient un taux de croissance plus élevé que les souches porteuses des mutations A2142C, A2143 ou A2142T. Les données de cette étude indiquent pourquoi les isolats cliniques d'H. pylori résistants à la clarithromycine sont plus susceptibles les isolated d'H. pylori résistants d'être porteurs de mutations A2142G ou A2143G et occasionnellement, seulement de mutations A2142C.
$\mathrm{C}$ larithromycin is a macrolide antibiotic (1) frequently used in Canada as a part of triple therapy for eradication of Helicobacter pylori from the human stomach (2). Until recently, the prevalence of clarithromycin-resistant $H$ pylori was considered to be low (less than $5 \%$ ) in most countries, but as high as 10\% in France and Belgium. However, resistance to clarithromycin appears to be increasing worldwide, with values a high as $27 \%$ reported in Italy (3). If a strain of
H pylori is resistant to clarithromycin, it is found to be much more difficult to eradicate using triple therapy. Therapy failure among patients with clarithromycin-resistant isolates has been reported to be between $20 \%$ and $60 \%$ (4). In a small Canadian study performed using Alberta isolates collected between 1992 and 1995, 3\% (one strain) were found to be resistant to clarithromycin (5). Further multicentre trials are required in Canada to determine whether the inci-

Proceedings of The Canadian Helicobacter Study Group 5th Meeting, Ottawa, Ontario, June 11 to 13, 1999

Department of Medical Microbiology and Immunization, University of Alberta, Edmonton, Alberta

Correspondence: Dr Diane E Taylor, Department of Medical Microbiology and Immunology, 1-28 Medical Sciences Building, University of

Alberta, Edmonton, Alberta T6G 2H7. Telephone 780-492-4777, fax 780-492-7521, e-mail Diane.Taylor@ualberta.ca

Received for publication May 9, 2000. Accepted June 13, 2000 
TABLE 1

Mutations in the Helicobacter pylori 23S rRNA gene and associated macrolide, lincosamide and streptogramin phenotypes

$\operatorname{MIC}^{*}(\mu \mathrm{g} / \mathrm{mL})$

\begin{tabular}{lcccccc}
$\begin{array}{l}\text { H pylori } \\
\text { strain }\end{array}$ & $\begin{array}{c}\text { 23S rRNA gene } \\
\text { mutation }\end{array}$ & Cla & Cln & Qnp & Dfp & RP59500 \\
\hline UA802 & Wild-type & 0.004 & 32 & 4 & 8 & 2 \\
A & A2143G & 4 & 256 & 4 & 8 & 2 \\
B & A2143G & 1 & 256 & 4 & 8 & 0.5 \\
D & A2142G & 8 & $>512$ & 64 & 8 & 1 \\
E & A2142G & 16 & $>512$ & 128 & 8 & 1 \\
UA802-Cla ${ }^{r}-1$ & A2142G & 16 & $>512$ & 128 & 8 & 2 \\
\hline
\end{tabular}

*Determined by agar dilution testing (9). Cla Clarithromycin; Cln Clindamycin; Dfp Dalfopristin (streptogramin A); Qnp Quinupristin (streptogramin B); MIC Minimum inhibitory concentration

dence of clarithromycin resistance is increasing and is, therefore, jeopardizing the use of this important antibiotic for the eradication of $\mathrm{H}$ pylori.

\section{MECHANISM OF ACTION OF CLARITHROMYCIN}

Clarithromycin binds to the 23S rRNA within the 50 S ribosomal subunit of the $70 \mathrm{~S}$ ribosome (1). It inhibits protein synthesis by blocking the translocation step and thus interfering with the release of unchanged transfer RNA molecules bound to the peptidyl transferase site on the ribosome (6).

\section{MECHANISM OF CLARITHROMYCIN RESISTANCE}

Resistance to clarithromycin was first reported by Versalovic and collaborators (7) from Abbott laboratories in the United States and also by a group in Holland (8). Sequencing of polymerase chain reaction (PCR) products prepared from primers complementary to the 23S rRNA genes from Escherichia coli (7) or H pylori (8) demonstrated mutations at two positions in the domain $\mathrm{V}$ loop of $23 \mathrm{~S}$ rRNA: adenine at position 2058 or 2059 to guanine using the $E$ coli coordinates (1). Taylor et al (9) cloned and sequenced both copies of the 23S-5S gene cluster from $H$ pylori UA802. The 5 ' terminus of the mature $23 \mathrm{~S}$ rRNA gene transcript was determined by primer extension, and the complete nucleotide sequence of H pylori 23S rRNA genes was shown to consist of 2967 base pairs and to be identical to one another (9). Natural DNA transformation was used to prepare clarithromycin-resistant $\left(\mathrm{Cla}^{\mathrm{r}}\right)$ isolates of UA802, using $\mathrm{Cla}^{\mathrm{r}}$ strains from Ireland; strain $\mathrm{E}$ had a minimum inhibitory concentration (MIC) of 16 to $32 \mu \mathrm{g} / \mathrm{mL}$ and strain B had an MIC of 0.5 to $1 \mu \mathrm{g} / \mathrm{mL}$. The MIC of UA802 was 0.002 to $0.008 \mu \mathrm{g} / \mathrm{mL}$. Transformation frequencies were $2.4 \times 10^{-6} \pm 0.47 \times 10^{-6}$ per viable cell using $H$ pylori strain B DNA and $1.9 \times 10^{-6} \pm 0.47 \times{ }^{10-6}$ per viable cell using $H$ pylori E DNA. Sequencing of PCR products prepared from UA802 transformants that were $\mathrm{Cla}^{\mathrm{r}}$ demonstrated that those with DNA acquired from strain $\mathrm{B}$ and $\mathrm{E}$ had undergone A2143G and A2142G mutations, respectively (9). The $H$ pylori $23 \mathrm{~S}$ rRNA coordinates determined from the primer extension work (9) have been used in subsequent studies.

Mutational resistance to clarithromycin appears to depend on the presence of a small number of copies of rRNA genes in the genome. The complete sequences of $\mathrm{H}$ pylori 26695 (10) and H pylori J99 (11) confirmed evidence from pulsed-field gel maps of several $\mathrm{H}$ pylori strains, indicating that there are only two copies of 23S rRNA genes per genome (12). In contrast, E coli strains contain seven copies (1). Bacterial species that contain multiple rRNA copies and that acquire resistance to macrolides frequently do so by acquisition of a methylase enzyme, which introduces methyl groups to the adenosine residues at similar positions in $23 \mathrm{~S}$ rRNA (at E coli coordinates 2058 and 2059) (1). Mutations in these residues in strains with a low number of $23 \mathrm{~S}$ rRNA copies appear to be recent evolutionary events. They were first described in Mycobacterium intracellulare, a bacterium with a single $23 \mathrm{~S}$ rRNA gene (13). In contrast, the methylases that modify adenine residues in 23S RNA have been reported for many years (1).

The $\mathrm{H}$ pylori mutations that generate either $\mathrm{A} 2143 \mathrm{G}$ or A2142G at positions in 23S rRNA appear to prevent effective binding of macrolide antibiotics to the $23 \mathrm{~S}$ ribosomal subunit and thus allow protein synthesis to proceed normally. Nevertheless, mutations at the first position, A2142G, confer higher levels of resistance to macrolides than those at the second position, A2143G. MICs are usually 0.5 to $4 \mu \mathrm{g} / \mathrm{mL}$ for $\mathrm{A} 2143 \mathrm{G}$ and 8 to $32 \mu \mathrm{g} / \mathrm{mL}$ for A2142G with clarithromycin $(9,14)$. Most frequently, both copies of the mutated 23S rRNA have identical sequences, although a few heterozygotes (one copy wild-type and one copy mutated) have been described (reviewed in 9). These heterozygotes are expected to have an intermediate level of resistance to clarithromycin.

\section{RESISTANCE TO MACROLIDE, LINCOSAMIDE AND STREPTOGRAMIN B ANTIBIOTICS IN H PYLORI}

Methylation or mutation at A2058 in Staphylococcus aureus $23 \mathrm{~S}$ rRNA as well as in other bacteria confers complete cross-resistance to the macrolide, lincosamide and type B streptogramin (MLS) antibiotics (MLS resistance) (1), suggesting that these structurally distinct antibiotics have similar effects in inhibiting ribosomal function. Mutations within the vicinity of 2059 or 2057 have also been associated with resistance to the macrolide group of antibiotics (1). Wang and Taylor (14) found that, in H pylori $23 \mathrm{~S}$ rRNA, the A2142G mutation is linked to high level cross-resistance to all MLS antibiotics. In contrast, the A2143 mutation gave rise to an intermediate level of resistance to clarithromycin and clindamycin (a lincosamide) but did not confer resistance to streptogramin B (Table 1).

In addition, streptogramin A (dalfopristin) and streptogramin B (quinupristin) were demonstrated to have a synergistic effect on both MLS-sensitive (A2059G) and MLS- 
resistant (A205SG) H pylori strains (14). The combination of these antibiotics, called RP59500 or Synercid (Rhone Poulenc Rorer, Germany) inhibited both $\mathrm{Cla}^{r}$ and clarithromycin-susceptible $\mathrm{H}$ pylori, which had an MIC of 0.5 to $2 \mu \mathrm{g} / \mathrm{mL}$. Therefore, these data suggests that quinupristin-dalfopristin could be considered a possible alternative antibiotic in the case of failure of therapy with clarithromycin-based treatment - once licensing has been achieved and a suitable oral formulation is available.

\section{WHY DO ONLY CERTAIN TYPES OF MUTATIONS PREDOMINATE IN CLARITHROMYCIN-RESISTANT H PYLORI?}

Most of the $\mathrm{Cla}^{\mathrm{r}}$ mutations observed in clinical isolates involve A2058G or A2059G transitions in 23S rRNA, only very occasionally adenine $(\mathrm{A})$ to cytosine $(\mathrm{C})$ transitions were observed and no A to thymine $(\mathrm{T})$ equivalent to uracil (U) in $23 \mathrm{~S}$ rRNA $(7-9,14,15)$. To determine the reason(s) for the prevalence of A to guanine $(G)$ transitions in $\mathrm{Cla}^{\mathrm{r}}$ $\mathrm{H}$ pylori in vitro site-directed mutagenesis was performed within domain $\mathrm{V}$ of the 23S rRNA gene. The site-directed mutants were introduced into $H$ pylori UA802 by natural transformation, followed by confirmatory DNA sequencing (14).

Using this method, we were able to construct mutants with each of the following mutations: A2142G, A2142C, A2142T, A2143G and A2143C at a transformation frequency of approximately $1 \times 10^{-5}$ per viable cell.

The MICs of clarithromycin for the five types of mutants are shown in Table 2. The results found with in vitro constructed mutants agree with those found in clinical isolates. Mutations at position 2142 always confer a higher level of clarithromycin resistance than mutations at position 2143. At the 2142 position an $\mathrm{A}$ to $\mathrm{G}$ or an $\mathrm{A}$ to $\mathrm{C}$ mutation gives rise to similar MICs that are higher than those conferred by the A to $\mathrm{T}$ mutation (14).

The growth rates of the different types of site-directed mutants were examined (14). The growth rates of the A2142G and A2143G mutants were similar to those of wildtype $H$ pylori UA802. In contrast, A to C and A to T mutations resulted in slower growth rates, with an extra day lag period. Because the mutations associated within $\mathrm{Cla}^{\mathrm{r}}$ are within the $23 \mathrm{~S}$ rRNA, it is possible that $\mathrm{A}$ to $\mathrm{C}$ or $\mathrm{A}$ to $\mathrm{T}$ mutations impair ribosomal function in protein synthesis and that A to G mutations do not, whether or not clarithromycin is bound to the ribosome. Multiplex sequence analysis was used to demonstrate quantitatively the competitive growth advantage of A to $G$ mutants over the other types of mutants (16). The order of preference of competitive accumulation of the $\mathrm{H}$ pylori $\mathrm{Cla}^{\mathrm{r}}$ mutants in culture is A2142G greater than A2143G much greater than A2142C greater than A2143C (A2142T). If the same is true in vivo, once an A to $G$ mutation occurs (spontaneously or drug-induced), the other types of mutations that are present in the same environment, if any, are likely to be overgrown after a period of time. A to $\mathrm{C}$ or $\mathrm{A}$ to $\mathrm{T}$ mutants can be isolated only when an A to $G$ mutant has not appeared at that particular gastric
TABLE 2

Characteristics of clarithromycin-resistant Helicobacter pylori generated in vitro, isolated after natural transformation of polymerase chain reactions products as described in reference 14

\begin{tabular}{lc}
\hline Mutation* & MIC $(\mu \mathrm{g} / \mathbf{m L})$ \\
\hline A2142G & 16 \\
A2142C & 16 \\
A2142T & 4 \\
A2143G & 4 \\
A2143C & 4 \\
\hline *Mutation in 23S rRNA genes (9). MIC Minimum inhibitory concentration
\end{tabular}

niche. It has also been postulated $(14,16)$ that an additional hypothetical mechanism by which the A to $G$ mutations (transitions) are preferentially produced in $\mathrm{H}$ pylori may also contribute to their observed predominance among $\mathrm{Cla}^{\mathrm{r}}$ isolates.

\section{CONCLUSIONS}

With the use of clarithromycin as part of triple therapy for eradication of $\mathrm{H}$ pylori, resistance appears to be increasing in clinical isolates of this bacterium. Resistance is always chromosomal and has not been found to be plasmid-mediated. Mutations at two positions within 23S rRNA have been found to be responsible for clarithromycin resistance. The A2142G and A2143G mutations have no effect on growth rates of $H$ pylori, whereas other mutations at these positions produced by in vitro mutagenesis (A2142C, A2143C and A2142T) appear to result in slower growth rates. These results explain the prevalence of $A 2142 G$ and $A 2143 G$ in clinical isolates of $H$ pylori.

ACKNOWLEDGEMENTS: Dr Taylor is an Alberta Heritage Foundation for Medical Research Scientist. This work is supported by The Canadian Bacterial Diseases Network and by The National Cancer Institute of Canada, with funding from the Terry Fox Run.

\section{REFERENCES}

1. Weisblum B. Macrolide resistance. Drug Resist Update 1998;1:29-41.

2. Veldhuyzen van Zanten SJ, Sherman PM, Hunt RH. Helicobacter pylori: new developments and treatments. CMAJ 1997;156:1565-74.

3. Glupczynski Y. Presentation at The Canadian Helicobacter Study Group 5th Meeting, Ottawa, June 11 to 13, 1999.

4. Cayla R, Zerbib F, Talbi P, Megraud F, Lamouliatte H. Pre- and posttreatment clarithromycin resistance of Helicobacter pylori strains: a key factor of treatment of failure. Gut 1995;37(Suppl 1):A55. (Abst)

5. Taylor DE, Jiang Q, Fedorak RN. Antibiotic susceptibilities of Helicobacter pylori strains isolated in the Province of Alberta. Can J Gastroenterol 1998;12:295-8.

6. Spahn CM, Prescott CD. Throwing a spanner in the works: antibiotics and the translation apparatus. J Mol Med 1996;74:423-39.

7. Versalovic J, Shortridge D, Kibler K, et al. Mutations in 23S rRNA are associated with clarithromycin resistance in Helicobacter pylori. Antimicrob Agents Chemother 1996;40:477-80.

8. Debets-Ossenkopp YJ, Sparrius M, Kusters JG, Kolkman JJ, Vandenbroucke-Grauls CM. Mechanism of clarithromycin resistance in clinical isolates of Helicobacter pylori. FEMS Microbiol Lett 1996;142:37-42. 
9. Taylor DE, Ge Z, Purych D, Lo T, Hiratsuka K. Cloning and sequence analysis of two copies of a $23 \mathrm{~S}$ rRNA gene from Helicobacter pylori and association of clarithromycin resistance with $23 \mathrm{~S}$ rRNA mutations. Antimicrob Agents Chemother 1997;41:2621-8

10. Tomb JF, White $\mathrm{O}$, Kerlavage AR, et al. The complete genome sequence of the gastric pathogen Helicobacter pylori. Nature 1997;388:539-47.

11. Alm RA, Ling LS, Moir DT, et al. Genomic-sequence comparison of two unrelated isolates of the human gastric pathogen Helicobacter pylori. Nature 1999;397:176-80.

12. Jiang Q, Hiratsuka K, Taylor DE. Variability of gene order in different Helicobacter pylori strains contributes to genome diversity. Mol Microbiol 1996;20:833-42.
13. Meier A, Kirschner P, Springer B, et al. Identification of mutations in $23 \mathrm{~S}$ rRNA gene of clarithromycin-resistant Mycobacterium intracellulare. Antimicrob Agents Chemother 1994;38:381-4.

14. Wang G, Taylor DE. Site-specific mutations in the $23 \mathrm{~S}$ rRNA gene of Helicobacter pylori confer two types of resistance to macrolidelincosamide-streptogramin B antibiotics. Antimicrob Agents Chemother 1998;42:1952-8.

15. Stone GG, Shortridge D, Flamm RK, et al. Identification of a $23 \mathrm{~S}$ rRNA gene mutation in clarithromycin-resistant Helicobacter pylori. Helicobacter 1996;1:227-8.

16. Wang G, Rahman MS, Humayun MZ, Taylor DE. Multiplex sequence analysis demonstrates the competitive growth advantage of the A-toG mutants of clarithromycin-resistant Helicobacter pylori. Antimicrob Agents Chemother 1999;43:683-5. 


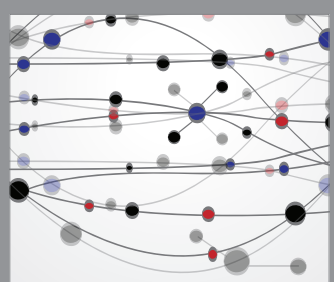

The Scientific World Journal
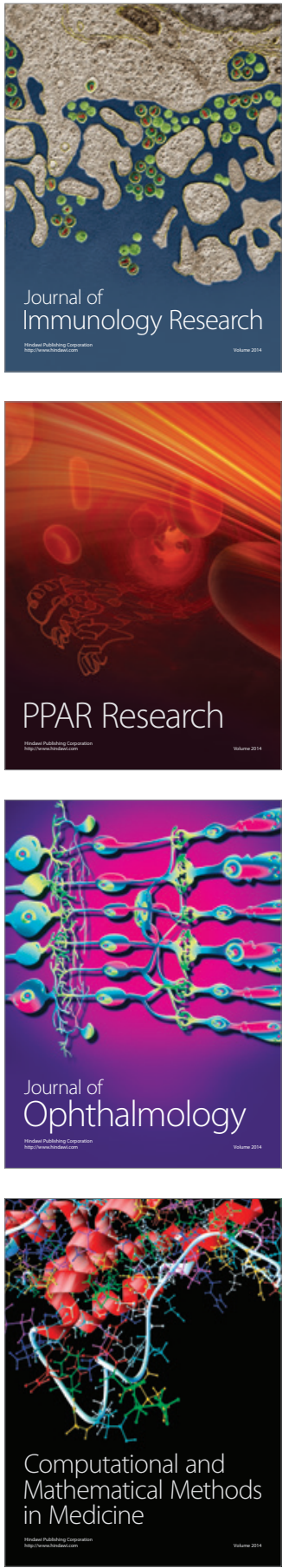

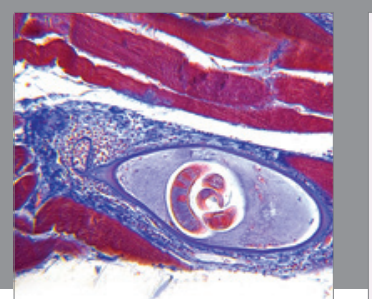

Gastroenterology Research and Practice

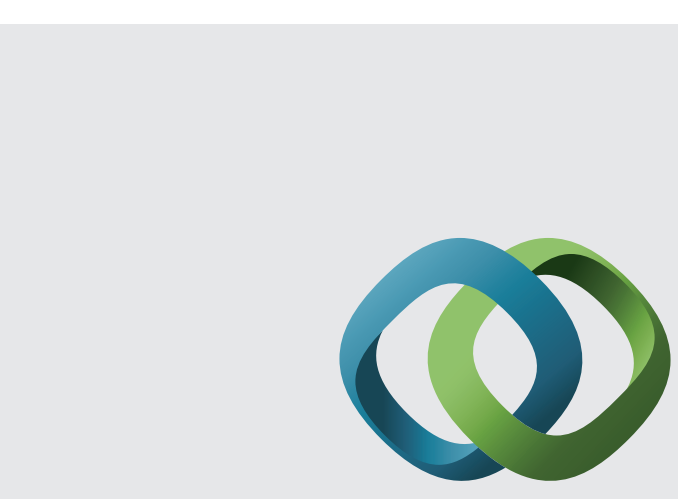

\section{Hindawi}

Submit your manuscripts at

http://www.hindawi.com
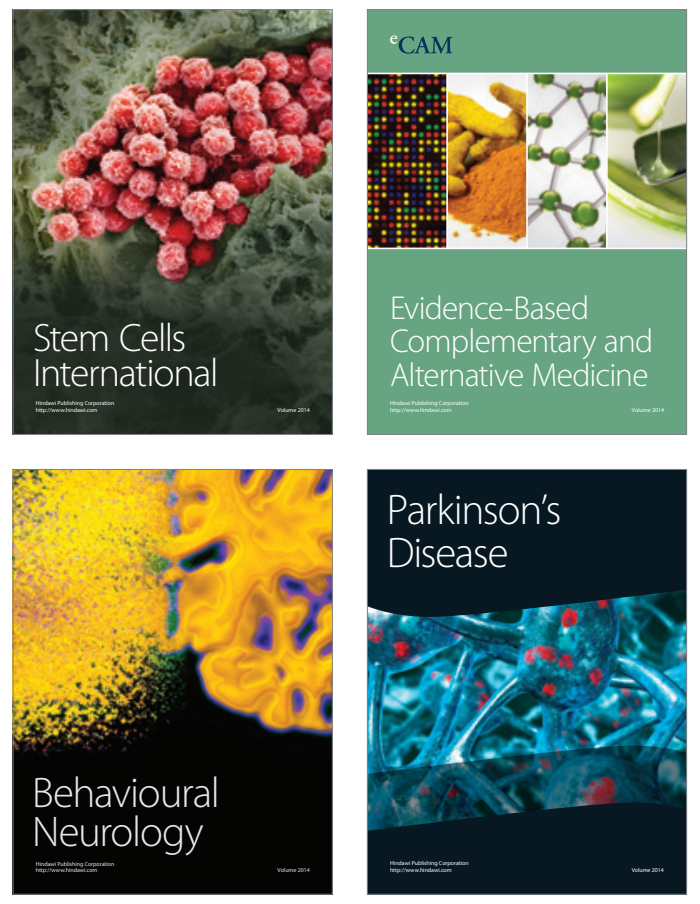
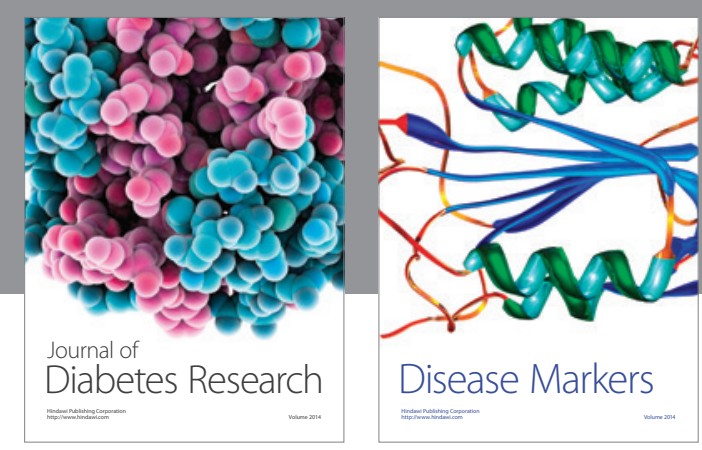

Disease Markers
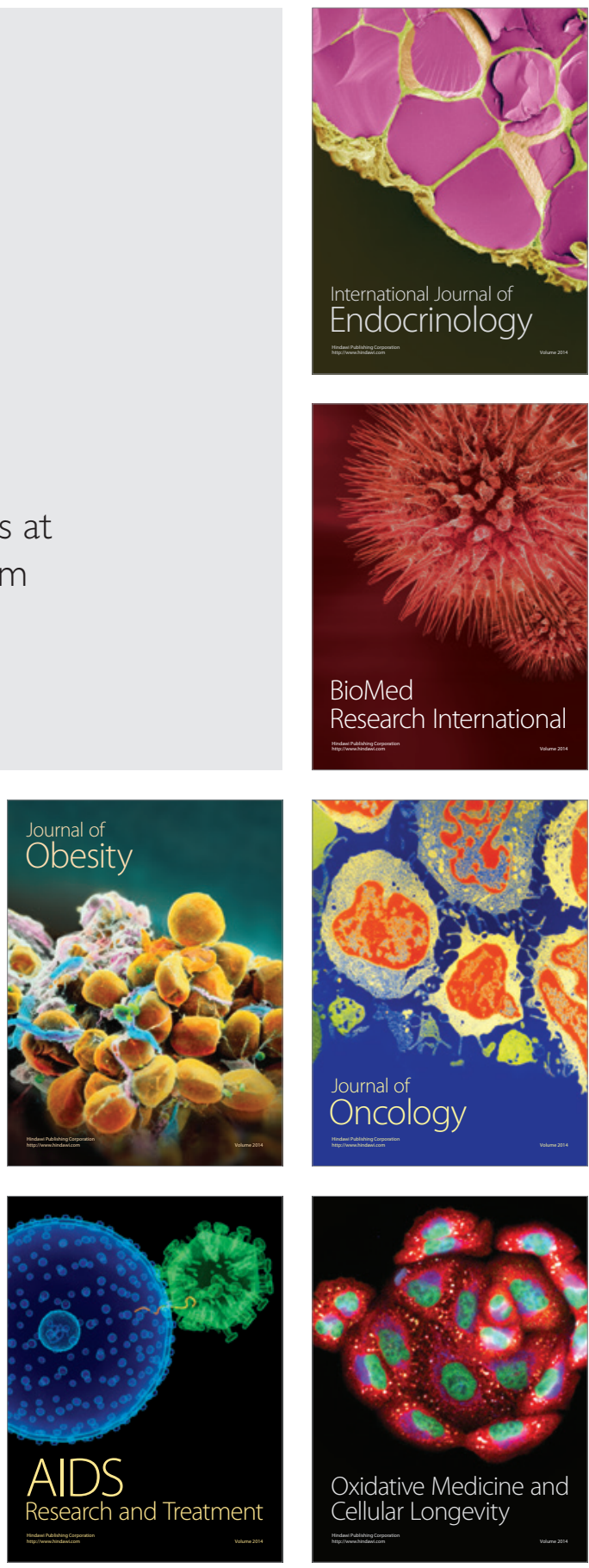